\title{
Reductive Carboxylation of Acetyl Phosphate by Cell-free Extracts of Mixed Rumen Micro-organisms
}

\author{
By B. EMMANUEL* AND L. P. MILLIGAN \\ Department of Animal Science, The University of Alberta, \\ Edmonton, Alberta, Canada
}

(Received 23 February 1973; revised 9 April 1973)

INTRODUCTION

Acetate is one of the major products of carbohydrate fermentation in the rumen. Pyruvate synthase, which catalyses the reductive carboxylation of acetyl-CoA to pyruvate, has been detected in photosynthetic (Evans \& Buchanan, I965; Evans, 1968) and anaerobic bacteria (Bachofen, Buchanan \& Arnon, 1964; Andrew \& Morris, 1967). Our object was to investigate the existence in rumen micro-organisms of pyruvate synthase, which would add to an understanding of metabolic utilization of acetate in the rumen.

\section{METHODS}

One rumen-fistulated cow, which was fed $2.5 \mathrm{~kg}$ of concentrate (15.3\% protein) and $0.9 \mathrm{~kg}$ of good-quality alfalfa-bromegrass hay at $08.00 \mathrm{~h}$ and $\mathrm{I} 6.00 \mathrm{~h}$ daily, was used. The animal had free access to drinking water. The procedures employed for the study of reductive fixation of $\left[{ }^{14} \mathrm{C}\right]$ bicarbonate by extracts of rumen micro-organisms and for isolation and chromatography of reaction products were described by Emmanuel \& Milligan (1972). The 2,4-dinitrophenylhydrazone of pyruvate was isolated by the procedure of Bessman, Rossen \& Layne (I953).

\section{RESULTS AND DISCUSSION}

The requirements for bicarbonate fixation are given in Table $\mathrm{I}$. The reaction was dependent on bacterial extract and reducing reagents. Acetyl phosphate and CoASH markedly stimulated the reaction, but thiamine pyrophosphate stimulated to a lesser extent. Acetyl$\mathrm{CoA}$, as well as acetate plus ATP and $\mathrm{CoASH}$, was effective as the substrate. The fixation was maximum at $\mathrm{pH} 7.5$ and then decreased more sharply on the basic side than the acidic side of this optimum. The relationship between bacterial extract and fixation was of a curvilinear nature; fixation increased up to inclusion of $0.7 \mathrm{mg}$ of extract protein in the assay. The product yielded a 2,4-dinitrophenylhydrazone which migrated with the hydrazone of pyruvic acid on paper chromatography $\left(R_{F} 0 \cdot 26\right)$. When $50 \mu$ moles of NADH and I mmole of $\mathrm{NH}_{4} \mathrm{Cl}$ were added to the reaction mixture a product was formed, which, after isolation by column chromatography (Emmanuel \& Milligan, 1972), migrated with alanine $\left(R_{F} 0.37\right)$. The radioactivity on the paper chromatogram was coincident with the ninhydrinreactive spot.

Acetyl phosphate was active as a substrate in the presence of $\mathrm{CoASH}$, presumably because of the existence of phosphotransacetylase (EC. 2.3.I.3), which is active in rumen

* Present address: School of Veterinary Medicine, Pahlavi University, Shiraz, Iran. 
Table I. Requirements for $\left[{ }^{14} \mathrm{C}\right]$ bicarbonate fixation by extracts of mixed rumen micro-organisms

$\begin{array}{lc}\text { Treatment } & \begin{array}{c}\text { Total } \\ \text { radioactivity } \\ \text { fixed } \\ \text { (d.p.m.) }\end{array} \\ \text { Complete* } & 4750 \\ \text { Minus thiamine pyrophosphate } & 3000 \\ \text { Minus CoASH } & 1860 \\ \text { Minus acetyl phosphate } & 1000 \\ \text { Minus bacterial extract } & 300 \\ \text { Minus reducing reagents } & 300\end{array}$

* The complete reaction mixture contained Sephadex-treated (G-10) bacterial extract, $0.5 \mathrm{mg}$ protein; potassium phosphate buffer ( $\mathrm{pH} 7.5$ ), $150 \mu$ moles; ATP, $2.5 \mu$ moles; $\mathrm{MgCl}_{2}, 5 \mu$ moles; CoASH, $0.25 \mu$ mole; acetyl phosphate, $5 \mu$ moles; thiamine pyrophosphate, $2 \mu$ moles; sodium bicarbonate, $5 \mu$ moles (containing I I $2 \mu \mathrm{Ci} \mathrm{NaH}{ }^{14} \mathrm{CO}_{3}, 47 \mathrm{mCi} / \mathrm{mmole}$ ). The reducing system was composed of $0.5 \mu \mathrm{g}$ methyl viologen, I $50 \mu \mathrm{g}$ ferredoxin and zinc powder (enough to reduce the methyl viologen). The final volume was $0.8 \mathrm{ml}$. The reaction mixture was incubated at $37^{\circ} \mathrm{C}$, in a shaking bath, for $30 \mathrm{~min}$.

micro-organisms (Joyner \& Baldwin, I966). Acetyl-CoA synthetase (EC. 2.I.I) (I I $\mu$ mole hydroxamate $/ \mathrm{h} / \mathrm{mg}$ extract protein), measured by the methods of Stadtman \& Barker (1950), was also active in our extracts of rumen micro-organisms.

Our results provide evidence for the occurrence of pyruvate synthase in extracts of mixed rumen micro-organisms. This is in agreement with the report by Allison \& Peel (I 97 I) that they obtained some evidence for pyruvate synthetase activity in Peptostreptococcus elsdenii. Reductive carboxylation of acetate to form pyruvate would, in principle, be analagous to the ruminal occurrence of reductive carboxylations of a number of other organic acids (Allison, I969; Milligan, I970). In other work, label from ${ }^{14} \mathrm{CO}_{2}$ (Otagaki, Black, Goss \& Kleiber, I955) and from $\left[{ }^{14} \mathrm{C}\right]$ acetate (Hoover, Kesler \& Flipse, 1963; Allison, Bucklin \& Robinson, 1966) was incorporated into microbial protein by mixed rumen micro-organisms. In their study, Allison et al. (1966) found that alanine was labelled abundantly relative to other amino acids. As a result of examination of the requirements of 89 freshly isolated strains and 35 old, laboratory strains, Bryant \& Robinson (I962) noted that acetate is important, as evidenced by stimulation of growth, in the nutrition of many species of rumen bacteria. Thus, conversion of acetate to pyruvate, logically in cells that do not otherwise produce adequate amounts of pyruvate, is probably one means of utilization of acetate and of $\mathrm{CO}_{2}$ for synthesis by micro-organisms in the rumen.

The support of the Canada Department of Agriculture and the National Research Council of Canada is gratefully acknowledged.

\section{REFERENCES}

Allison, M. J. (1969). Biosynthesis of amino acids by ruminal microorganisms. Journal of Animal Science 29, 797-807.

Allison, M. J., Bucklin, J. A. \& Robinson, I. M. (1966). Importance of the isovalerate carboxylation pathway of leucine biosynthesis in the rumen. Applied Microbiology 14, 807-814.

Allison, M. J. \& PeeL, J. L. (197I). The biosynthesis of valine from isobutyrate by Peptostreptococcus elsdenii and Bacteroides ruminocola. Biochemical Journal r2I, 43 I-437.

ANDrew, I. G. \& MoRrIs, J. G. (1967). The biosynthesis of alanine by Clostridium kluyveri. Biochemica et biophysica acta 97, 176-179. 
Bachofen, R., Buchanan, B. B. \& Arnon, D. I. (1964). Ferrodoxin as a reductant in pyruvate synthesis by a bacterial extract. Proceedings of the National Academy of Sciences of the United States of America $\mathbf{5 1}$, 690-694.

Bessman, S. P., Rossen, J. \& LAYNe, E. C. (1953). $\gamma$-Aminobutyric acid-glutamic acid transaminase in brain. Journal of Biological Chemistry 201, 385-39I.

Bryant, M. P. \& Robinson, I. M. (I962). Some nutritional characteristics of predominant culturable ruminal bacteria. Journal of Bacteriology 84, 605-6I4.

Emmanuel, B. \& Milligan, L. P. (1972). Enzymes of the conversion of succinate to glutamate in extracts of rumen microorganisms. Canadian Journal of Biochemistry 50, I-8.

Evans, M. C. W. (1968). Ferredoxin dependent synthesis of 2-ketoglutarate and pyruvate by extracts of the green photosynthetic bacterium Chloropseudomonas ethylicum. Biochemical and Biophysical Research Communications 33, I46-I 50.

Evans, M. C. W. \& Buchanan, B. B. (1965). Photoreduction of ferredoxin and its use in carbon dioxide fixation by a subcellular system from a photosynthetic bacterium. Proceedngs of the National Academy of Sciences of the United States of America 53, 1420-I 425.

Hoover, W. H., Kesler, E. M. \& Flipse, R. J. (1963). Carbon sources for in vitro protein synthesis by rumen bacteria. Journal of Dairy Science 46, 733-739.

JoYNER, A. E. \& BAIDwin, R. L. (I966). Enzymatic studies of pure cultures of rumen microorganisms. Journal of Bacteriology 92, I $32 \mathrm{I}-1330$.

Milligan, L. P. (1970) Carbon dioxide fixing pathways of glutamic acid synthesis in the rumen. Canadian Journal of Biochemistry 48, 463-468.

Otagaki, K. K., Black, A. L., Goss, H. \& Kleiber, M. (I955). In vitro studies with rumen microorganisms using carbon-14-labelled casein, glutamic acid, leucine and carbonate. Journal of Agricultural and Food Chemistry 3, 948-95I.

Stadtman, E. R. \& Barker, H. A. (1950). Fatty acid synthesis by enzyme preparations of Clostridium kluyveri. Journal of Biological Chemistry 184, 769-793. 